\title{
REVIEW
}

\section{Aflibercept: a Potent Vascular Endothelial Growth Factor Antagonist for Neovascular Age-Related Macular Degeneration and Other Retinal Vascular Diseases}

\author{
Raafay Sophie · Abeer Akhtar · Yasir J. Sepah · Mohamed Ibrahim · Millena Bittencourt · Diana V. Do · \\ Quan Dong Nguyen
}

To view enhanced content go to www.biologicstherapy-open.com Received: December 15, 2011 / Published online: May 29, 2012

(c) The Author(s) 2012. This article is published with open access at Springerlink.com

\section{ABSTRACT}

Introduction: In the western hemisphere, age-related macular degeneration (AMD) is the leading cause of visual loss in the elderly. Currently approved therapies for AMD include argon laser, photodynamic therapy, and antivascular endothelial growth factor (VEGF) therapy. The index review discusses aflibercept (VEGF Trap-Eye) in the context of current anti-VEGF therapies for neovascular AMD and other retinal vascular diseases. It highlights important differences between VEGF Trap-Eye and currently used anti-VEGF therapies for neovascular AMD; and discusses the efficacy

R. Sophie · A. Akhtar · Y. J. Sepah · M. Ibrahim • M. Bittencourt · D. V. Do · Q. D. Nguyen $(\varangle)$ Retinal Imaging Research and Reading Center, Wilmer Eye Institute, Johns Hopkins University School of Medicine, Baltimore, 600 North Wolfe Street, Maumenee 745, Maryland 21287, USA

e-mail: qnguyen4@jhmi.edu

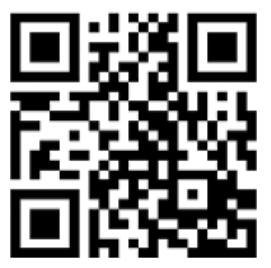

Enhanced content for Biologics in Therapy articles is available on the journal web site: www.biologicstherapy-open.com of these treatments utilizing information from landmark clinical trials.

Methods: A systematic search of literature was conducted on PubMed, Science Direct, and Scopus with no limitations of language or years of publication.

Results: Preclinical studies have shown that VEGF Trap-Eye binds to VEGF-A with a higher affinity than other anti-VEGF molecules; and that it also binds to placental growth factor (PlGF). In clinical trials, VEGF Trap-Eye has been shown to be as effective in the treatment of neovascular AMD as other anti-VEGF therapies and possibly to have a longer duration of drug activity.

Conclusion: VEGF Trap-Eye has enhanced the treatment options currently available for the management of neovascular AMD. The comparable efficacy of VEGF Trap-Eye (to other anti-VEGF agents) coupled with its longer dosing interval may decrease the number of annual office visits for patients with AMD and their caregivers.

Keywords: Aflibercept; Age-related macular degeneration; Antivascular endothelial growth factor; Neovascular age-related macular degeneration; Vascular endothelial growth factor Trap-Eye 


\section{INTRODUCTION}

Age-related macular degeneration (AMD) is the leading cause of visual loss and visual disability in patients aged $\geq 50$ years in Europe and North America [1-4]. The Age-Related Eye Disease Study (AREDS) has categorized AMD into three stages: early, intermediate, and advanced. Advanced AMD is defined as having foveal geographic atrophy or presence of choroidal neovascularization (CNV). Geographic atrophy is characterized by atrophy of the retinal pigment epithelium and loss of the photoreceptor layers. Neovascular (wet) AMD is characterized by choroidal neovascularization. While nonneovascular (dry) AMD accounts for $90 \%$ of cases of AMD, neovascular AMD is responsible for majority of cases of severe vision loss due to AMD [5].

Traditionally, CNV lesions of neovascular AMD are classified into classic or occult on fluorescein angiography (FA), which differ in clinical course and response to various treatment modalities [6]. Classic lesions demonstrate early hyperfluorescence and are usually well circumscribed. Occult lesions are poorly defined and show late hyperfluorescence. A predominantly classic lesion includes more than $50 \%$ classic $\mathrm{CNV}$, a minimally classic lesion includes less than 50\% classic CNV, and an occult lesion includes less than $1 \%$ classic CNV.

In recent years, a classification for $\mathrm{CNV}$ lesions based on multiple imaging modalities (FA, indocyanine green angiography, and spectral domain optical coherence tomography [OCT]) has been employed [7, 8]. Such classification categorizes $\mathrm{CNV}$ lesions as type 1 (CNV beneath the retinal pigment epithelium [RPE]), type 2 (CNV that has penetrated the $\mathrm{RPE} /$ Bruch membrane complex and is present in the subretinal layer above the RPE), and type 3 (intraretinal neovascularization formerly referred to as retinal angiomatous proliferation [RAP]), based on their anatomic location [9].

\section{METHODS OF LITERATURE REVIEW}

Studies were identified through a comprehensive literature search of electronic databases (PubMed, Science Direct, and Scopus) with no limitations of language or year of publication. The following keywords and combinations of words were used in compiling the above search: 'aflibercept,' 'vascular endothelial growth factor' (VEGF), 'VEGF,' 'antivascular endothelial growth factor' (anti-VEGF), 'anti-VEGF,' 'vascular endothelial growth factor Trap-Eye,' 'VEGF Trap-Eye,' 'agerelated macular degeneration,' 'neovascular agerelated macular degeneration,' 'AMD,' 'diabetic macular edema' (DME), 'DME,' 'retinal vein occlusion' (RVO), 'RVO,' 'branch retinal vein occlusion' (BRVO), 'BRVO,' 'central retinal vein occlusion' (CRVO), and 'CRVO.'

\section{CURRENTLY APPROVED THERAPIES FOR NEOVASCULAR AMD}

Current established therapies for the treatment of neovascular AMD include argon laser therapy, photodynamic therapy (PDT), and anti-VEGF therapy.

\section{Laser Therapy}

Thermal laser photocoagulation has been approved for extrafoveal or juxtafoveal classic CNV based on results from the Macular Photocoagulation Study conducted in the1980s [10-13].

\section{Photodynamic Therapy}

In April 2000, the US Food and Drug Administration (FDA) approved verteporfin for treating patients with predominantly 
classic subfoveal CNV secondary to AMD [14]. The approval was based on the results of the Treatment of Age-Related Macular Degeneration with Photodynamic Therapy (TAP) Study [15]. Results from the TAP and Verteporfin in Photodynamic Therapy (VIP) studies have also allowed the Centers for Medicare and Medicaid Services to cover PDT for occult and minimally classic lesions less than four disc areas in size [16].

\section{Anti-VEGF Therapy}

In December 2004, the FDA approved intravitreal (IVT) administration of $0.3 \mathrm{mg}$ pegaptanib sodium every 6 weeks for the treatment of all forms of neovascular AMD [17]. Two years later, in June 2006, monthly IVT injections of ranibizumab (RBZ) $0.5 \mathrm{mg}$ were approved for the treatment of neovascular AMD [18]. On November 18, 2011, the FDA approved VEGF Trap-Eye for the treatment of patients with neovascular AMD. The recommended dosage of VEGF Trap-Eye injection is $2 \mathrm{mg}$ given every 4 weeks for the first 12 weeks, followed by $2 \mathrm{mg}$ every 8 weeks [19].

\section{Surgery}

The Submacular Surgery Trial (SST), a large, randomized clinical trial, has not established any significant benefit of surgery in patients with AMD [20, 21]. Surgical therapies, including submacular surgery and macular translocation, are currently recommended only in neovascular AMD cases where anti-VEGF therapy has not been shown to be effective [22].

Table 1 Comparison among different VEGF antagonists

\begin{tabular}{|c|c|c|c|c|}
\hline & Aflibercept & Ranibizumab & Bevacizumab & Pegaptanib \\
\hline $\begin{array}{l}\text { Molecular } \\
\text { structure }\end{array}$ & $\begin{array}{l}\text { Fusion protein: domains } \\
\text { of VEGFR1 and } \\
\text { VEGFR2 fused with } \\
\text { IgG1 Fc }[26]\end{array}$ & $\begin{array}{l}\text { Monoclonal IgG } \\
\text { antibody fragment (Fab) } \\
{[31]}\end{array}$ & $\begin{array}{l}\text { Monoclonal IgG } \\
\text { antibody [32] }\end{array}$ & $\begin{array}{l}\text { RNA aptamer-secreted } \\
\text { protein }[33]\end{array}$ \\
\hline $\begin{array}{l}\text { Mechanism of } \\
\text { action }\end{array}$ & $\begin{array}{l}\text { Binds to all forms of } \\
\text { VEGF-A, VEGF-B, and } \\
\text { PlGF }[26,27]\end{array}$ & $\begin{array}{l}\text { Binds to all forms of } \\
\text { VEGF-A [31] }\end{array}$ & $\begin{array}{l}\text { Binds to all forms of } \\
\text { VEGF-A [30] }\end{array}$ & $\begin{array}{l}\text { Binds to VEGF-A } 165 \\
\text { [33] }\end{array}$ \\
\hline $\begin{array}{l}\text { Half-life in } \\
\text { vitreous humor }\end{array}$ & $\begin{array}{l}4.79 \text { days } \\
\text { (in rabbits) [29] }\end{array}$ & $\begin{array}{l}2.88-2.89 \text { days for } \\
0.5 \mathrm{mg} \text { (in rabbits) } \\
{[31,34] 2.63 \text { and }} \\
3.9 \text { days for } 0.5 \mathrm{mg} \text { and } \\
2 \mathrm{mg} \text { (in monkeys) [35] }\end{array}$ & $\begin{array}{l}4.32-6.61 \text { days for } \\
1.25 \mathrm{mg} \text { (in rabbits) [32] } \\
6.7 \text { days for } 1.25 \mathrm{mg} \\
\text { (in humans) [30] }\end{array}$ & $\begin{array}{l}10 \pm 4 \text { days (in humans) } \\
{[33,36]}\end{array}$ \\
\hline FDA approval & Neovascular AMD [28] & $\begin{array}{l}\text { Neovascular AMD, } \\
\text { macular edema } \\
\text { secondary to retinal vein } \\
\text { occlusion }[18,37]\end{array}$ & $\begin{array}{l}\text { Metastatic renal and } \\
\text { colorectal cancers; } \\
\text { glioblastoma; } \\
\text { non-small cell lung } \\
\text { cancer [38] } \\
\text { Off-label use for AMD }\end{array}$ & Neovascular AMD [17] \\
\hline
\end{tabular}

$A M D$ age-related macular degeneration, Fab fragment antigen binding, $F D A$ Food and Drug Administration, $I g G 1 F c$ immunoglobulin G1 Fragment, crystallizable, $P l G F$ placental growth factor, $R 1$ receptor $1, R 2$ receptor 2 , $R N A$ ribonucleic acid, $V E G F$ vascular endothelial growth factor 


\section{NOVEL PHARMACOLOGIC AGENTS AS TREATMENTS FOR NEOVASCULAR AMD}

A variety of molecules are currently being studied for the treatment of neovascular AMD. These drugs target various mediators and receptors involved in the angiogenic pathway. They include tyrosine kinase inhibitors (valatinib, pazopanib, TG100801, TG101095, AG013958, AL39324), integrin inhibitors (JSM6427, volociximab), bioactive lipids (sonepcizumab), nicotine receptor antagonists (mecamylamine), vectors encoding for pigment epithelial derived factor (ADGVPEDF) and small interfering RNAs or siRNAs (PF-04523655, AGN211745, RTP801i-14) [23, 24].

The class of drugs that has shown to be most effective against angiogenesis is the VEGF antagonists [25]. The efficacy of these agents has been studied extensively in several phase 3 trials resulting in a paradigm shift in the management of neovascular AMD. A summary of the properties of anti-VEGFs currently employed in managing patients with neovascular AMD is presented in Table 1 [17, 18, 26-38].

\section{THE VEFG PATHWAY}

VEGF is an important mediator of neovascularization. It also increases vessel permeability, and is about 50,000 times more potent than histamine in inducing vascular leakage [39]. The mammalian VEGF family includes VEGF-A, VEGF-B, VEGF-C, VEGF-D, and PIGF (placental growth factor). VEGF- $\mathrm{A}_{165}$ is the most abundantly expressed and biologically active form in the human body [40].

VEGF-A acts on two transmembrane receptors located on the vascular endothelium, VEGFR1 and VEGFR2. Each receptor has seven immunoglobulin (Ig) domains in their extracellular regions. Binding of these domains with VEGF initiates the intrinsic tyrosine kinase activity of their cytodomains. Although VEGFR1 binds to VEGF with substantially higher affinity, most of the biologic effects of VEGF appear to be mediated by VEGFR2 [26]. Activation of these tyrosine kinases activates pathways that mediate endothelial migration and proliferation promoting angiogenesis; as well as effecting endothelial barrier functions causing leakage of water and macromolecules [41]. PIGF binds to VEGFR1 and has been shown to facilitate VEGF-A in promoting angiogenesis and vascular permeability, especially in pathological states [42-44].

VEGF- $A_{165}$ and VEGF- $A_{121}$ are most abundantly expressed in normal eye vasculature and high levels of these isoforms have been found in $\mathrm{CNV}$ tissues excised from AMD patients [43]. VEGF- $A_{164}$ and VEGF- $A_{120}$ have also been implicated in the pathogenesis of CNV [45]. VEGF-A and PlGF have both been shown to promote angiogenesis and vascular leakage in the retina of animal and human models [43, 45-47].

\section{VEGF TRAP-EYE (AFLIBERCEPT INJECTION)}

\section{Structure and Mechanism of Action}

VEGF Trap-Eye (aflibercept injection) is a recombinant protein consisting of the fragment, crystallizable (Fc) portion of human immunoglobulin (Ig) G1 fused with human extracellular domains of VEGFR1 and VEGFR2 (Fig. 1).

It is created using "Traps" technology developed at Regeneron Pharmaceuticals, Inc., in which parts of two receptors are fused together along with an immunoglobulin constant region to create a soluble decoy receptor that has higher binding affinity to their cognate ligands than the 
individual receptors themselves [48]. The VEGF Trap mRNA construct consists of sequences encoding the signal sequence of VEGFR1, fused with the Ig domain 2 of VEGFR1, which is fused to the Ig domain 3 from VEGFR2, which in turn is fused to the Fc domain of IgG1. There are no intervening sequences in this fusion construct. The VEGF Trap protein is then expressed as a secreted protein by Chinese hamster ovary $(\mathrm{CHO})$ $\mathrm{K} 1$ cells with the signal sequence removed. The final protein molecule is a dimeric glycoprotein
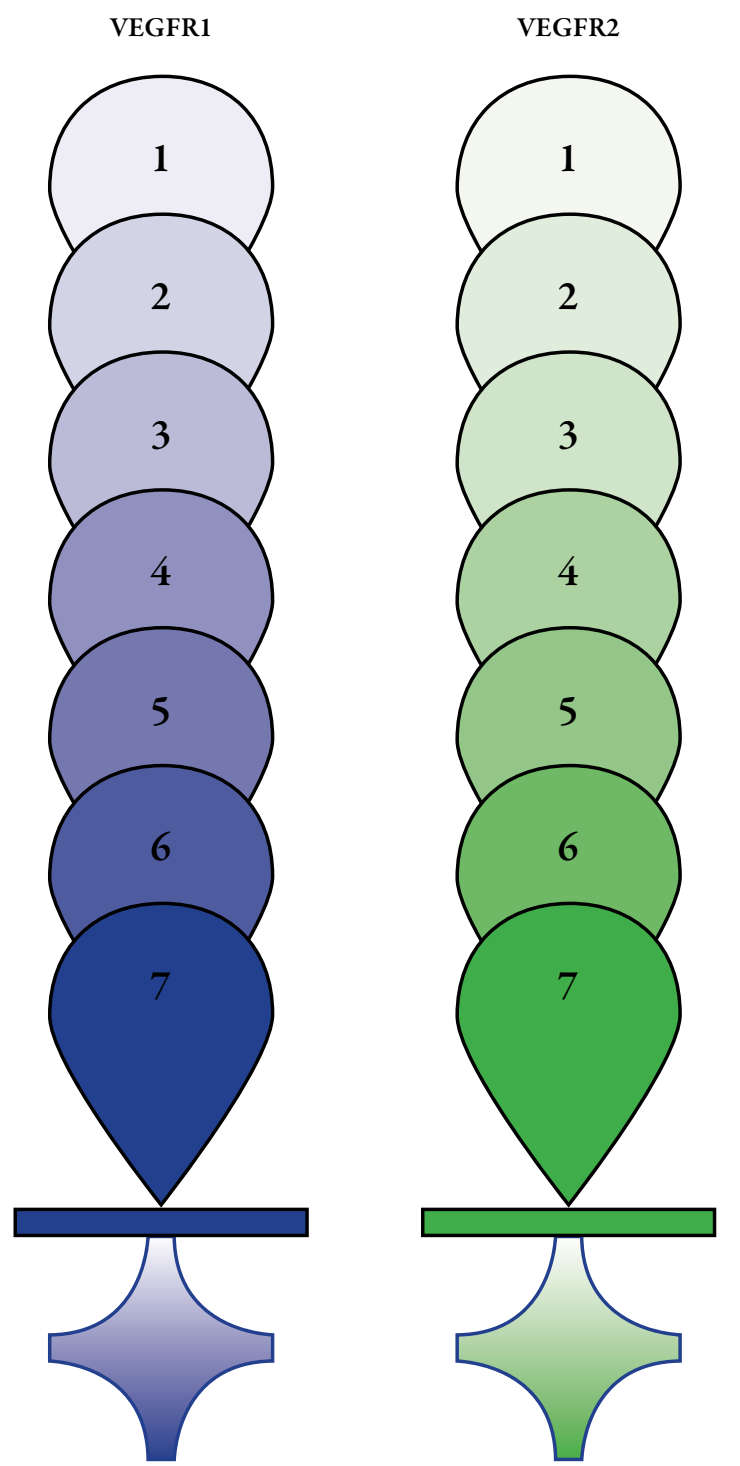

with a protein molecular weight of $97 \mathrm{kDa}$ and contains $\sim 15 \%$ glycosylation to give a total molecular weight of $115 \mathrm{kDa}$ [49].

Final preparation of VEGF Trap-Eye involves ultra-purification of the VEGF Trap molecule by a combination of filtration and chromatographic techniques, which is then followed by titration of VEGF Trap into a buffer solution that is compatible with ocular tissues.

\section{Pharmacodynamics}

VEGF Trap has a significantly higher affinity for VEGF-A (Kd 0.5-1 pmol/L) [26, 27, 50] than other monoclonal anti-VEGF antibodies (Kd 0.1-10 nmol/L) [51, 52]. It has a higher affinity for the VEGF ligand than even natural VEGF receptors found on vessels and binds to VEGF in a $1: 1$ ratio. In addition to binding to all isoforms of VEGF-A, VEGF Trap also binds to VEFG-B and PIGF $[28,39]$. When given IVT, VEGF Trap is rapidly distributed to the retina and is slowly absorbed into the systemic circulation with a mean $\mathrm{C}_{\max }$ of unbound VEGF Trap of

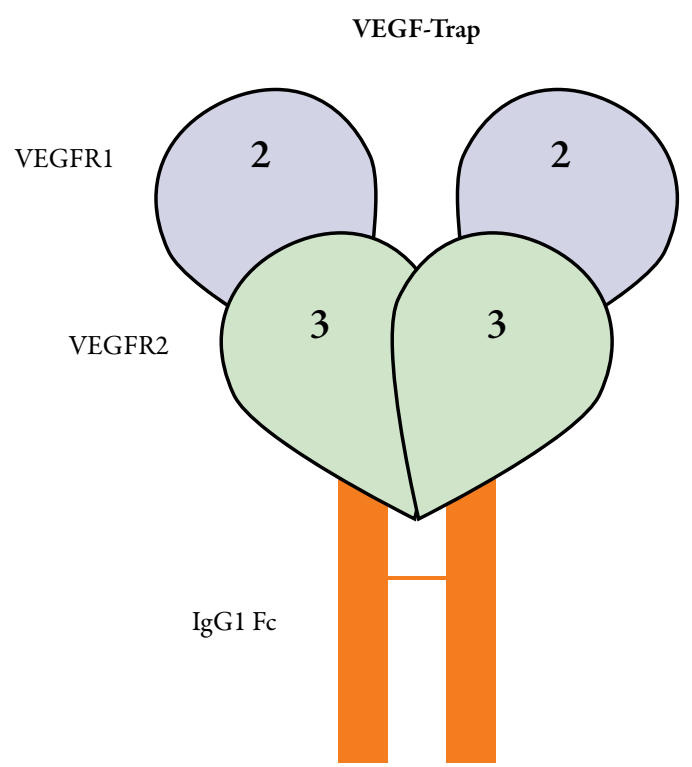

Fig. 1 Molecular construct of aflibercept, showing its possession of components from VEGF receptor 1 and VEGF receptor 2. $I g G 1 F_{\mathrm{c}}$ immunoglobulin G1 Fragment, crystallizable, $V E G F$ vascular endothelial growth factor 
$0.019 \mu \mathrm{g} / \mathrm{mL}$ (range 0 to $0.054 \mu \mathrm{g} / \mathrm{mL}$ ) after a $2.0 \mathrm{mg}$ IVT injection occurring on the second day and declining rapidly to become undetectable in the circulation at approximately 7-14 days [28].

\section{Pharmacokinetics}

The half-life of human IVT VEGF Trap is unknown, but the half-life of IVT VEGF Trap given to animals is approximately 5 days [29]. Using a mathematical model based on known half-lives of bevacizumab (BVZ) in humans (6.7 days) and animals, the half-lives of VEGF Trap and RBZ in human eyes have been estimated to be 7.13 and 4.75 days, respectively [30, 53].

Free VEGF Trap is removed primarily from the circulation by binding to VEGF to form an inactive 1:1 complex, and also by pinocytotic mediated proteolysis [52]. The inert complex is cleared by renal filtration [27]. The estimated clearance for free and bound VEGF Trap is $0.88 \mathrm{~L} /$ day and $0.14 \mathrm{~L} /$ day respectively. The central volume of distribution of free VEGF Trap is $4.94 \mathrm{~L}$ and the half-maximal binding $(\mathrm{Km})$ of free VEGF Trap binding to VEGF in the systemic circulation is $2.91 \mu \mathrm{g} / \mathrm{mL}$ [54]. The half-life in systemic circulation increases with doses from 1.7 days at $0.3 \mathrm{mg} / \mathrm{kg}$ to 5.1 days at $7.0 \mathrm{mg} / \mathrm{kg}$ [50].

\section{Toxicity}

Free VEGF Trap plasma concentrations following IVT administration of doses of up to $4 \mathrm{mg}$ (approximately $0.057 \mathrm{mg} / \mathrm{kg}$ ) are about two to three-times lower than free VEGF Trap plasma concentrations observed following intravenous (IV) administration of doses $\geq 1 \mathrm{mg} / \mathrm{kg}$. Bound VEGF Trap plasma concentrations following IVT administration of doses of up to $2 \mathrm{mg}$ /eye are approximately 20 -fold lower than those observed following IV administration of doses of $0.3-4 \mathrm{mg} / \mathrm{kg}[28,54,55]$. Systemic adverse events have been reported at IV administration of doses $\geq 1 \mathrm{mg} / \mathrm{kg}$ [50]. Therefore, systemic effects with IVT administration are unlikely; systemic adverse events have not been demonstrated to be clearly related to VEGF Trap-Eye in phase 1, 2 , or 3 clinical trials. No ophthalmic toxicity of the drug has been noted, but serious adverse events (SAEs) consistent with IVT injection administration have been reported [56-67].

\section{Formulation}

Aflibercept (VEGF Trap-Eye) is available as a preservative-free, sterile, aqueous solution in a single-use, glass vial designed to deliver $0.05 \mathrm{~mL}$ VEGF Trap $(40 \mathrm{mg} / \mathrm{mL}$ in $10 \mathrm{mM}$ sodium phosphate, $40 \mathrm{mM}$ sodium chloride, $0.03 \%$ polysorbate 20 , and $5 \%$ sucrose, $\mathrm{pH} 6.2$ ) and needs to be stored at $2-8^{\circ} \mathrm{C}\left(36-46^{\circ} \mathrm{F}\right)$ [37].

\section{Dosing}

The recommended dosage of VEGF Trap-Eye for neovascular AMD, based on the approval by the FDA, is $2 \mathrm{mg}$ given every 4 weeks for the first 12 weeks, followed by 2 mg every 8 weeks. VEGF Trap-Eye may be dosed as frequently as $2 \mathrm{mg}$ every 4 weeks $[19,68]$.

\section{CLINICAL TRIALS WITH ANTI-VEGF PHARMACOLOGIC AGENTS AND IMPLICATIONS FOR NEOVASCULAR AMD THERAPY}

Table 2 [69-81] summarizes important trials that have influenced current management of AMD with anti-VEGFs. The VEGF Inhibition Study in Ocular Neovascularization (VISION) trials established that pegaptanib (PEG) prevented vision loss over a period of 2 years in all forms of AMD, but no comparison was drawn with the use of PDT. 


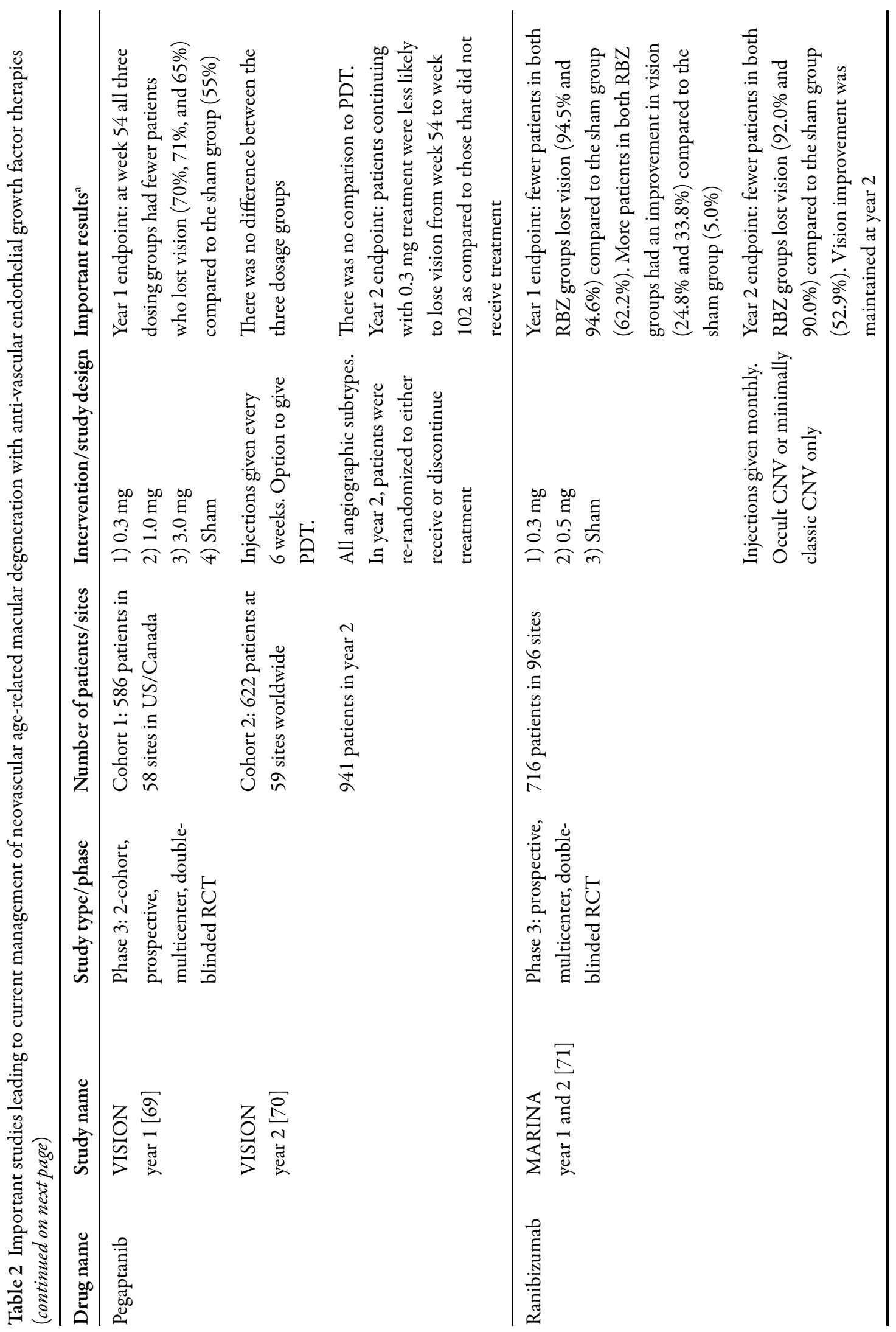




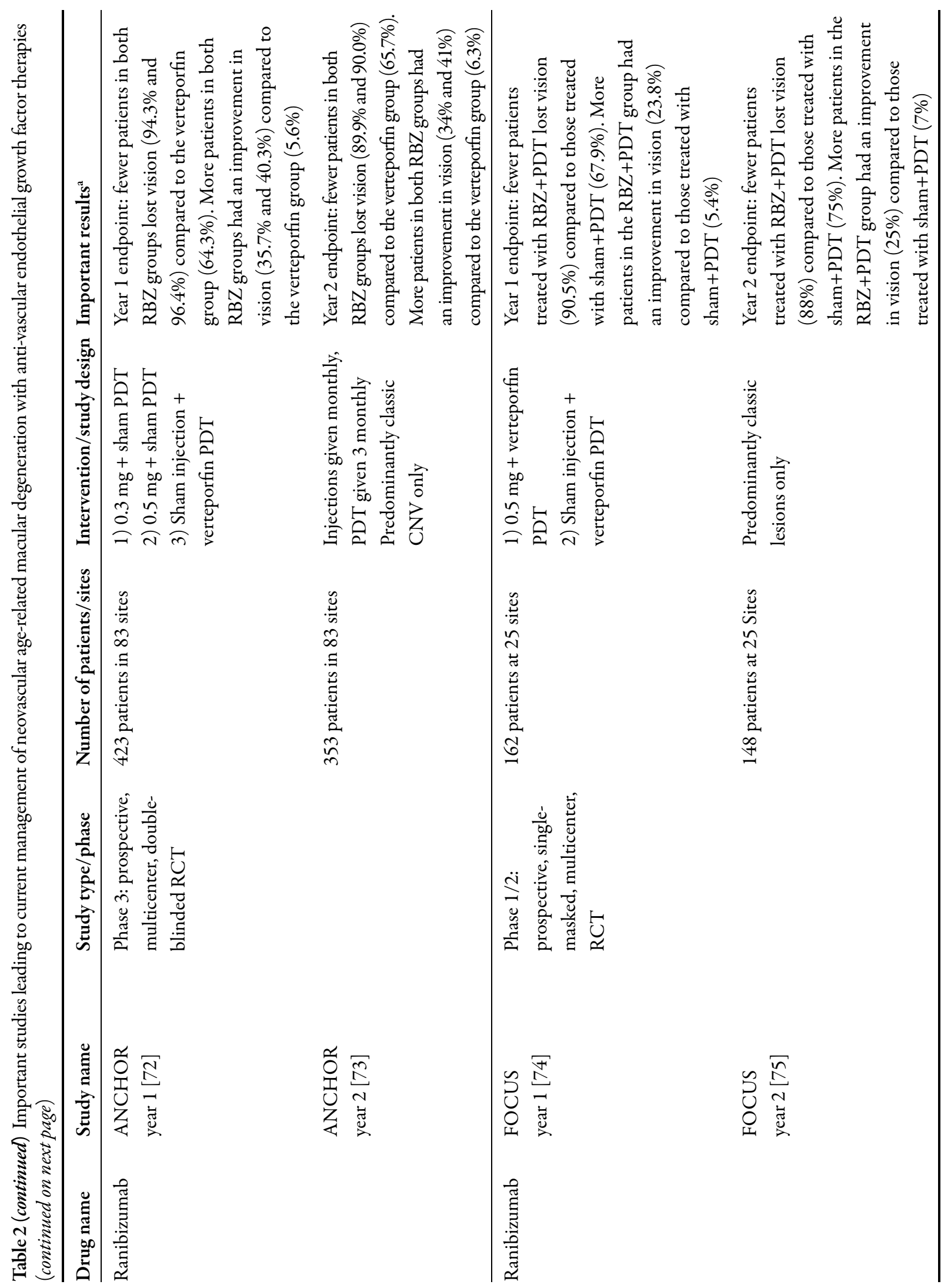




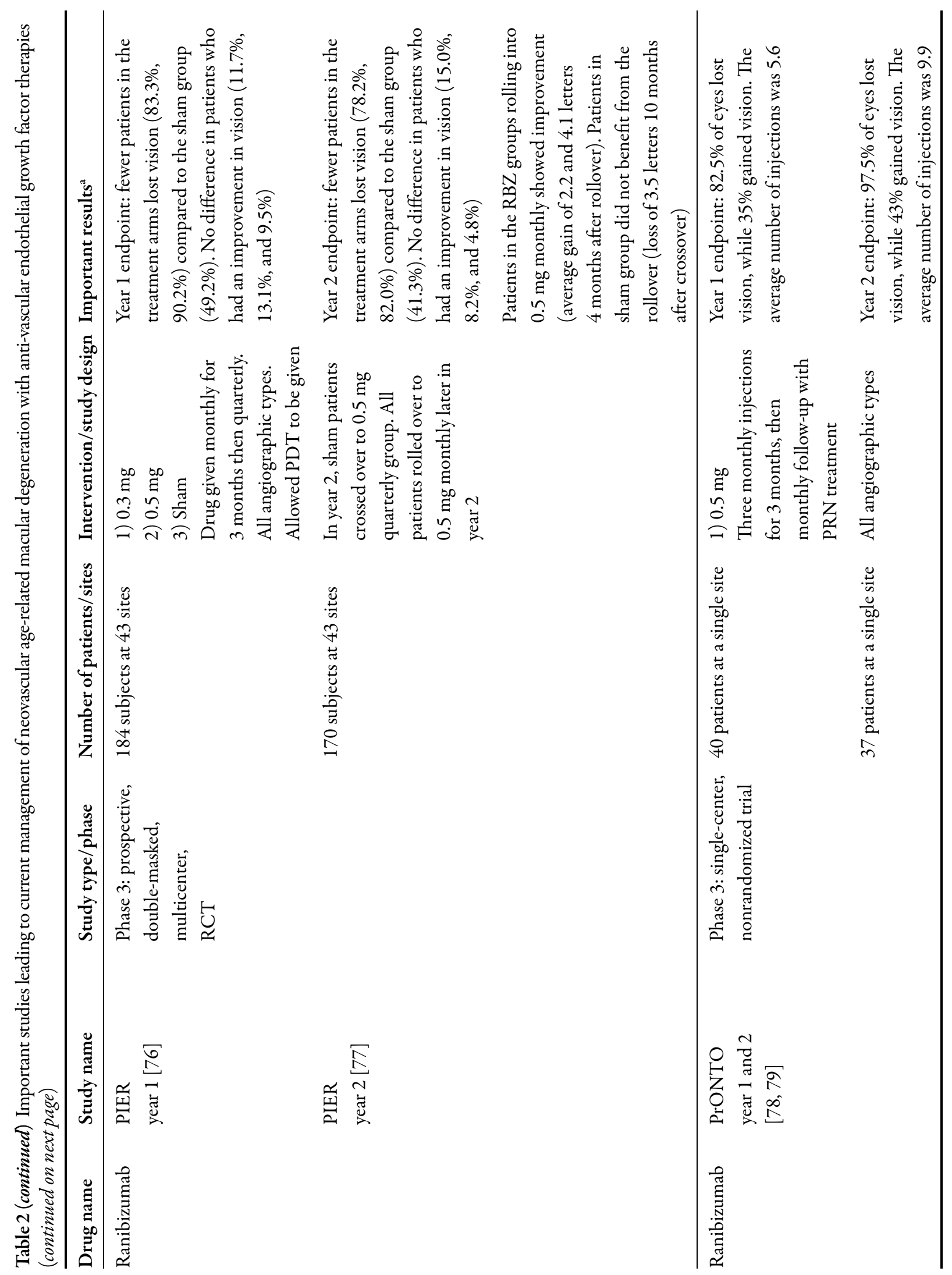




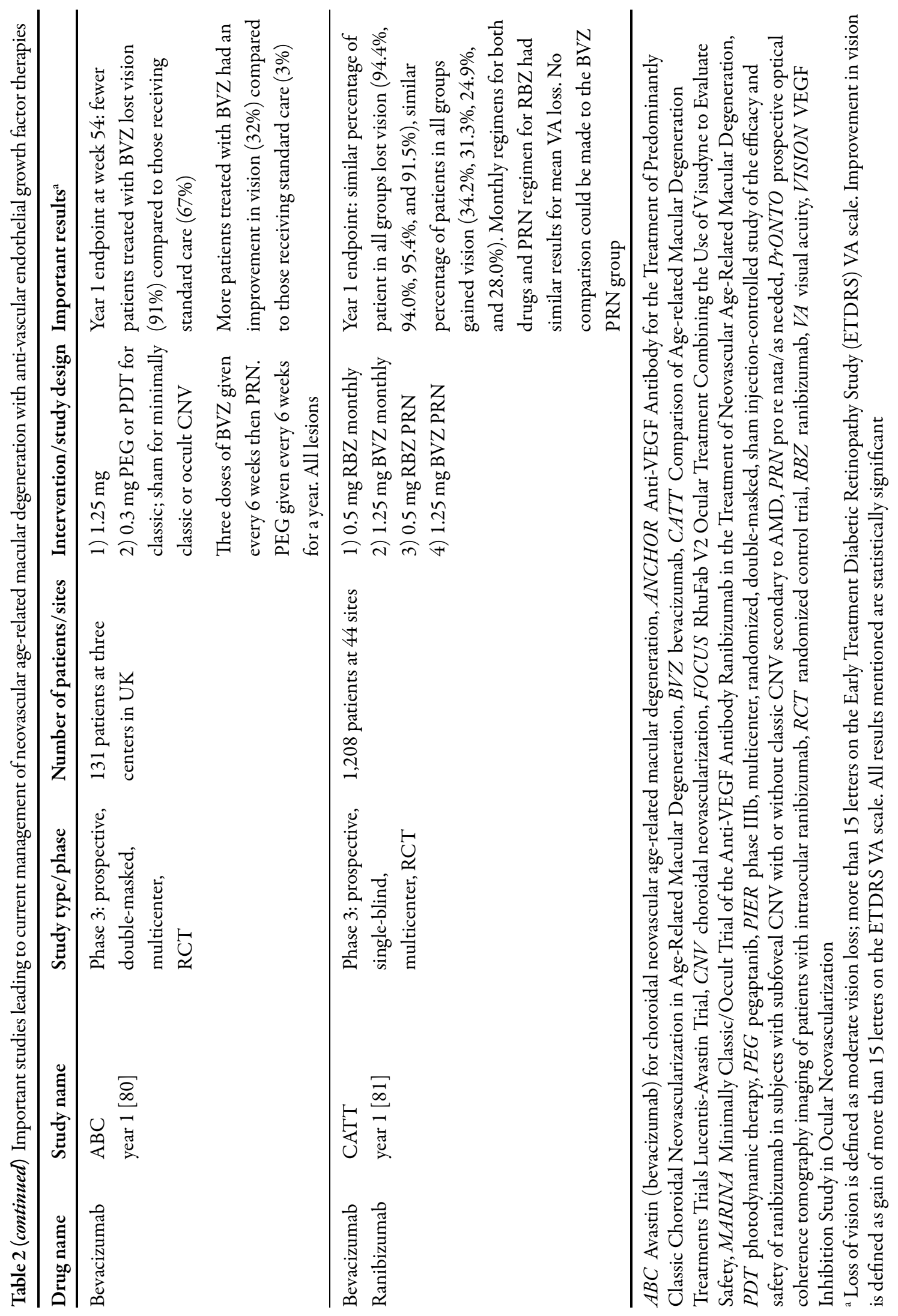


No significant gain in visual acuity (VA) was observed and the majority of patients continued to have vision loss with the use of pegaptanib in these trials $[69,70]$.

The Minimally Classic/Occult Trial of the Anti-VEGF Antibody Ranibizumab in the Treatment of Neovascular Age-Related Macular Degeneration (MARINA) and Anti-VEGF Antibody for the Treatment of Predominantly Classic Choroidal Neovascularization in AgeRelated Macular Degeneration (ANCHOR) trials established that RBZ not only prevented vision loss in all forms of AMD, but also improved vision in a subset of patients [71-73]. Patients in these trials were followed for 2 years and the results showed that the benefit of RBZ was maintained throughout the study period. In MARINA, there was a mean improvement of 5.4 and 6.6 letters in the treatment arms (vs. a mean decline of 14.9 letters in the sham arm). The ANCHOR study specifically compared RBZ to PDT for the treatment of predominantly classic lesions and showed that patients receiving RBZ maintained vision superiorly compared with PDT. In addition, RBZ improved VA in a larger subset of patients than PDT. Over 2 years, there was a mean improvement of 8.1 and 10.9 letters in the treatment arms (vs. a mean decline of 9.8 letters in the PDT arm).

The RhuFab V2 Ocular Treatment Combining the Use of Visudyne to Evaluate Safety (FOCUS) study has shown that PDT given in conjunction with RBZ is superior to PDT given alone for predominantly classic lesions [74, 75]. Due to the heavy financial burden and inconvenience of monthly injections of RBZ for a prolonged period, the phase $3 \mathrm{~b}$, multicenter, randomized, double-masked, sham injectioncontrolled study of the efficacy and safety of RBZ in subjects with subfoveal $\mathrm{CNV}$ with or without classic CNV secondary to AMD (PIER) and Prospective optical coherence tomography imaging of patients with intraocular ranibizumab (PrONTO) studies were conducted to explore and configure practical and economical regimens for RBZ administration. In the PIER study, monthly injections were given for 3 months followed by quarterly injections. However, it failed to show the same benefits that were seen when monthly injections were given in the MARINA and ANCHOR trials [76, 77]. On the other hand, the PrONTO study established that a regimen of 3 monthly injections followed by monthly follow-ups and PRN (pro re nata/ as needed) administration of RBZ is possible, with results comparable to the ANCHOR and MARINA trials. Patients in this study received an average of 5.6 injections at the end of year 1 and 9.9 injections by the end of year 2 . The PrONTO study, however, had a small sample size and was conducted at only one site [78, 79].

The Avastin (BVZ) for choroidal neovascular age-related macular degeneration $(\mathrm{ABC})$ trial has shown that BVZ, being a similar molecule to RBZ, also prevents vision loss along with improving VA in a subset of patients [80]. Both RBZ and BVZ have been shown to have similar efficacy in the Comparison of Age-related Macular Degeneration Treatments Trials: Lucentis-Avastin Trial (CATT) trials, when given in a monthly regimen. RBZ given on a PRN basis also has a comparable efficacy to the monthly regimens. No conclusive comparison could be made for the prnBVZ group from the CATT trial [81].

Another strategy, the "treat and extend" regimen (TER) has been suggested in the clinical setting [82]. TER involves treating patients with an anti-VEGF agent monthly until there is no macular hemorrhage on examination or any intra- or sub-retinal fluid on OCT. The treating interval is prolonged by 2 weeks for every visit that there is no recurrence of exudation until a 12 week interval is established. The patient is then given the option to discontinue treatment with a follow-up in 8 weeks or to continue 
12-weekly treatment. If at any time, there is evidence of recurrence of disease on examination, OCT or FA, or if VA is affected, the treatment interval is reduced by 2 weeks. Single-center retrospective studies using RBZ (92 eyes) and BVZ (74 eyes) have reported similar outcomes to those observed in MARINA and ANCHOR in eyes where TER was employed $[83,84]$. The superiority of this regimen has been shown over PRN dosing in another retrospective review of 90 eyes [85]. It is clear that the TER approach is more cost-effective than monthly injections; however, the level of evidence for the efficacy of this management approach is currently from retrospective trials. Nevertheless, such a strategy is currently being employed by the majority $(60 \%)$ of retinal specialists in the US as recently reported in the 2011 Preferences and Trends (PAT) Survey conducted by the American Society of Retina Specialists.

\section{CLINICAL TRIALS WITH VEGF TRAP-EYE (AFLIBERCEPT INJECTION) IN NEOVASCULAR AMD}

Preclinical studies have demonstrated the potential role of VEGF Trap in a number of vascular eye diseases including AMD $[60,86]$. VEGF Trap-Eye was first studied in humans by Nguyen and colleagues at the Wilmer Eye Institute via intravenous administration of $0.3 \mathrm{mg} / \mathrm{kg}, 1.0 \mathrm{mg} / \mathrm{kg}$ and $3.0 \mathrm{mg} / \mathrm{kg}$ against placebo in a phase 1 trial [61]. A dose-dependent decrease in foveal thickness (FTh) was noted, but due to two patients developing systemic toxicity in the $3.0 \mathrm{mg}$ group (grade 4 hypertension and grade 2 proteinuria), the trial was halted [61].

The CLinical Evaluation of Anti-angiogenesis in the Retina Intravitreal Trial (CLEAR-IT-1) clinical trial was a two-part phase 1 study designed to investigate the safety of IVT VEGF Trap for AMD. The first part of the study was a dose escalation cohort of increasing concentrations; $0.05,0.15,0.5,1,2$, and $4 \mathrm{mg}$ IVT VEGF Trap in 21 patients. No systemic or ocular adverse events (AEs) were noted. A substantial reduction in FTh was observed, and $95 \%$ of the patients remained stable or improved vision at 6 weeks [87]. The second part of the CLEAR-IT-1 study investigated the effect of a single intravitreal injection of 0.15 or $4 \mathrm{mg}$ of VEGF Trap in 28 patients, with the primary endpoint at week 8. No SAE was reported in either group. The effects were substantially more prominent in the $4 \mathrm{mg}$ group compared to the 0.15 group, as expected, illustrating the dose-response characteristics. FTh decreased by $25 \%$ and $11 \%$ while VA improved by a mean of 4.5 letters and 1.1 letters in the $4.0 \mathrm{mg}$ and $0.15 \mathrm{mg}$ groups, respectively [88].

The CLEAR-IT phase 2 (CLEAR-IT-2) multicenter, double-masked clinical trial followed 159 patients, divided into five groups across 33 sites, for a year. Two groups were administered a monthly injection of $0.5 \mathrm{mg}$ and $2.0 \mathrm{mg}$ VEGF Trap-Eye while three groups were given $0.5,2.0$, and $4.0 \mathrm{mg}$ VEGF Trap-Eye every 3 months. All patients received mandatory monthly or 3 monthly (based on the group designation) treatments for the first 3 months following the first treatment. After month 3, patients were evaluated each month and treated with the same dose of drug on a PRN basis. By the end of the mandatory treatment period, patients in groups 1 and 2 had received four treatments while patients in groups 3,4 , and 5 had received two treatments. The 3 -month results showed a mean reduction of $119 \mu \mathrm{m}$ in central subfield thickness and a mean gain of 5.7 letters across all groups. These improvements were significantly greater in the groups treated monthly compared to the groups treated 3-monthly [56]. Improvements in anatomic and functional parameters were maintained through 
month 13, with a mean reduction of $130 \mu \mathrm{m}$ in central subfield thickness and a mean gain of 5.3 letters across all groups. The size of CNV as observed at month 12 on FA decreased in all groups. Overall, $92 \%$ of the study population lost fewer than 15 letters and 22\% gained more than 15 letters. Patients received an average of two injections in the 9 months following the mandatory treatments [89].

The CLEAR-IT-2 trial showed that the monthly administration of VEGF Trap-Eye provided significantly greater improvement in both VA and foveal thickness (FTh) compared to every-3-month administration. The least number of injections (1.55) and the longest mean initial treatment-free interval (160 days) after mandatory treatments was observed in the $2.0 \mathrm{mg}$ monthly group. As highlighted before, the VEGF Trap-Eye molecule not only has a considerably favorable pharmacodynamic profile over other anti-VEGFs in its ability to bind to VEGF, it binds to PlGF as well. Such ability of persistent VEGF blockade led to the postulation of a possible longer treatment interval between injections of VEGF Trap compared to other anti-VEGFs. A mathematical model predicted VEGF Trap-Eye to maintain biological activity for 73-83 days compared to the activity of RBZ (30 days) [29]. On the basis of these results, phase 3 clinical trials VIEW 1 and VIEW 2 (The Vascular Endothelial Growth Factor [VEGF] Trap-Eye: Investigation of Efficacy and Safety in Wet Age-Related Macular Degeneration [AMD] Study) are being conducted.

VIEW 1 and VIEW 2 are two large, multicenter, randomized clinical trials that were designed to compare different treatment regimens of VEGF Trap-Eye to monthly RBZ. The studies were designed as noninferiority trials between VEGF Trap-Eye and RBZ. VIEW 1 has enrolled 1,217 patients across sites in North America, while VIEW 2 has enrolled 1,240 patients across sites in Europe, Asia, and Latin America. There are four treatment groups: $0.5 \mathrm{mg}$ RBZ monthly, 0.5 mg VEGF Trap-Eye monthly, 2 mg VEGF TrapEye monthly, and $2 \mathrm{mg}$ VEGF Trap-Eye every 2 months. All these groups received monthly injections for the first 3 months of the study [90].

At month 12, prevention of moderate vision loss (defined as losing less than 15 letters) was achieved in a similar percentage (94-95\%) of patients in all four treatment arms across both trials. Patients in the $2.0 \mathrm{mg}$ VEGF Trap-Eye group had a mean improvement of 10.9 letters in vision compared to 8.1 letters in the $0.5 \mathrm{mg}$ monthly RBZ group. The other two groups were found to be noninferior to $0.5 \mathrm{mg}$ RBZ monthly $[62,91]$. The VIEW study design did not compare against a dosing regimen of RBZ given every 2 months; thus, no comparison can be made to such a regimen.

In Year 2, all patients are being treated with the same dose no less frequently than every 3 months but as frequently as every month if required in a "quarterly capped PRN" dosing schedule $[64,92]$. According to a news release by Regeneron and Bayer on December 5, 2011, in an integrated analysis of the VIEW 1 and VIEW 2 studies, the VA gain from baseline in the VEGF Trap-Eye $2.0 \mathrm{mg}$ every other month group at week 96 was 7.6 letters compared to 8.4 letters at week 52 , with an average of 11.2 injections over 2 years and 4.2 injections during the second year. The VA gain from baseline in the monthly RBZ group at week 96 was 7.9 letters compared to 8.7 letters at week 52, with an average of 16.5 injections over two years and 4.7 injections during the second year. The results of each of the VIEW 1 and VIEW 2 studies were consistent with the integrated analysis [93].

The overall fewer average number of injections in the second year in the VEGF TrapEye $2.0 \mathrm{mg}$ every 2 months group compared to the RBZ group ( 4.2 vs. 4.7 ) was driven by the 
fact that fewer patients needed more intense therapy in the VEGF Trap-Eye $2.0 \mathrm{mg}$ every 2 months. The proportion of patients who required frequent injections (six or more) during the second year was $15.9 \%$ in the VEGF TrapEye $2.0 \mathrm{mg}$ every 2 months group compared to $26.5 \%$ in the RBZ group. In the $25 \%$ of patients who required the most intense therapy (the greatest number of injections), patients in the VEGF Trap-Eye $2.0 \mathrm{mg}$ every 2 months group required an average of 1.4 fewer injections in the second year compared to the RBZ group (6.6 vs. 8.0). In the $25 \%$ of patients in each group who had the fewest number of injections in the second year, the average number of injections was similar (approximately 3 for both groups, corresponding to the protocol-mandated minimum number of injections). The statistical significance of these differences was not disclosed in this press release [93]. In addition, based on the currently available information, it is not clear if the difference between 4.2 and 4.7 injections is clinically significant. Thus, it will be increasingly important to evaluate the efficacy and patterns of usage that are reported by clinicians as they begin to use aflibercept for neovascular AMD.

\section{VEGF TRAP-EYE AND OTHER RETINAL VASCULAR DISEASES}

In addition to neovascular AMD, VEGF Trap-Eye is also being studied as a potential therapy for DME and CRVO.

In an exploratory study of five patients, Do and colleagues at the Wilmer Eye Institute, demonstrated the safety and signals for bioactivity of VEGF Trap-Eye in eyes with DME. Each patient received one ITV injection of VEGF Trap-Eye. Four patients showed improvement in FTh (median $31 \%$ reduction from baseline) and VA (median improvement of three letters) at 6 weeks [59].
Following the pilot study, the DME And VEGF Trap-Eye: INvestigation of Clinical Impact (DAVINCI) phase 2 clinical trial compared $0.5 \mathrm{mg}$ and $2.0 \mathrm{mg}$ VEGF Trap-Eye monthly, $2 \mathrm{mg}$ VEGF Trap-Eye bimonthly, and 2 mg VEGF Trap-Eye PRN to the current standard of care (laser therapy) in 221 patients with DME $[65,66]$. Six month results showed all four groups to be superior (mean letters gain of 8.5 to 11.4, mean FTh reduction of $-127.3 \mu \mathrm{m}$ to $-194.5 \mu \mathrm{m})$ to macular laser therapy (mean letters gain of 2.4 , mean FTh $-67.9 \mu \mathrm{m}$ ) [58]. Month 12 results have shown that the superiority of VEGF TrapEye over laser has been maintained. Mean change in VA at week 52 was -1.3 letters for the laser group and 11, 13.1, 9.7, and 12 for the $0.5 \mathrm{mg}$ monthly, $2.0 \mathrm{mg}$ monthly, $2.0 \mathrm{mg}$ bimonthly, and $2.0 \mathrm{mg}$ PRN groups, respectively [94]. Two large phase 3 trials, Study of Intravitreal Administration of VEGF Trap-Eye in Patients with Diabetic Macular Edema (VISTA-DME) and VEGF Trap-Eye in Vision Impairment Due to DME (VIVD-DME), are currently investigating two separate dosing regimens of VEGF Trap-Eye compared to focal laser photocoagulation for the treatment of DME [67].

COPERNICUS (Controlled Phase 3 Evaluation of Repeated intravitreal administration of VEGF Trap-Eye In Central retinal vein occlusion: Utility and Safety) and GALILEO (General Assessment Limiting Infiltration of Exudates in central retinal vein Occlusion with VEGF TrapEye) are two phase 3 trials following 189 and 172 patients with CRVO respectively. Patients are given monthly $2.0 \mathrm{mg}$ VEGF Trap-Eye or sham injections for the first 6 months followed by PRN treatment for the next 6 months $[63,95]$. At month $6,56.1 \%$ and $60.2 \%$ of patients treated with VEGF Trap-Eye gained at least 15 letters from baseline compared to $12.3 \%$ and $22.1 \%$ of patients treated with sham, in the COPERNICUS and GALILEO studies, respectively [57, 94]. 
The multicenter, randomized, controlled trial, CRUISE (a study of the efficacy and safety of RBZ injection in patients with macular edema secondary to CRVO), in which 392 CRVO patients received 6 monthly RBZ or sham injections followed by PRN treatment, has previously reported that $46.2 \%$ and $47.7 \%$ of patients in the RBZ groups and $16.9 \%$ of patients in the sham group gained at least 15 letters at month 6 [96]. At month 12, 47\% and 50.8\% in the RBZ groups, and $33.1 \%$ in the sham/ RBZ group had a gain of at least 15 letters [97]. Three hundred and four patients from CRUISE were followed in the HORIZON (An OpenLabel, Multicenter Extension Study to Evaluate the Safety and Tolerability of Ranibizumab in Subjects With Choroidal Neovascularization [CNV] Secondary to AMD or Macular Edema Secondary to RVO Who Have Completed a Genentech-Sponsored Ranibizumab Study) trial and seen at least every 3 months in a PRN regimen. At month 24 after CRUISE, 38.6\% and $45.1 \%$ in the RBZ groups, and $38.3 \%$ in the sham/RBZ groups had a gain of at least 15 letters [98]. Phase 3 studies of VEGF TrapEye in branch retinal vein occlusion are being launched and will provide clinicians with additional and more complete data on the role of aflibercept in different types of RVO.

\section{SAFETY PROFILE OF ANTI-VEGF THERAPY: WHAT HAVE WE LEARNED}

Ocular SAEs after IVT injections in different clinical trials have been fortunately very low, with risks varying with underlying disease process, technique of administration and effect of the drug [99]. SAEs reported for anti-VEGF treatments specifically in multiple clinical trials have also been low with incidence rates per 100 injections as follows: endophthalmitis (0.04-0.11), retinal detachment (0.01-0.08), retinal tear $(0.02-0.3)$, anterior chamber inflammation (0.25-1.06), cataract (0.05-0.64), increased intraocular pressure (IOP; 0.15-3.6) and intraocular hemorrhage (0.03-00.18) [58, 100-102].

Since VEGF is involved in a variety of physiologic processes such as blood pressure homeostasis [103], the question of AEs due to any systemic circulation of anti-VEGF given intravitreally arises. BVZ and aflibercept when given intravenously as chemotherapeutic agents have been known to cause hypertension and proteinuria, while BVZ has been identified as a risk for arterial thrombotic events (ATEs) and venous thrombotic events (VTEs) [104]. In the ANCHOR and MARINA trials, an increased but not significant rate of nonocular hemorrhages was noted in the treatment arms (9\%) versus the sham arm (5.5\%), raising some concern [105]. However, in other RBZ trials, including a phase 4 study specifically designed to test the safety of RBZ injections (SAILOR-Safety Assessment of Intravitreal Lucentis for AMD), the rates of ATEs were similar to control groups [106]. In the CATT, the anti-VEGFs' incidences of ATEs and VTEs were between $2-3 \%$ and $0-1.4 \%$, respectively [81]. A large retrospective study of Medicare claims of 146,942 patients with neovascular AMD concluded that there was no increased risk of mortality, myocardial infarction, bleeding, or stroke in patients treated with BVZ and RBZ compared to photodynamic therapy or pegaptanib [107].

Thus far, data from the CLEAR-IT2 and VIEW studies have shown a similar safety profile as other anti-VEGFs. SAEs related to study injection, which included end ophthalmitis, traumatic cataract, and transient IOP elevation, were found to have an incidence of less than $0.1 \%$ per injection, consistent with SAEs of IVT therapy. The most commonly reported AEs are conjunctival hemorrhage, eye pain, cataract, vitreous detachment, vitreous floaters, and 
increased IOP. Data from the VIEW trials has been carefully analyzed to look for any systemic SAEs of VEGF Trap. Only $0.3 \%$ of patients were found to have had an SAE pertaining to hypertension, with mean systolic pressure remaining stable in all treatment groups over time. The incidence of ATEs was $1.8 \%$ in the VEGF Trap group compared to $1.3 \%$ in the RBZ group with no dose response found between drug and ATE events. There also appeared to be no increased risk of immunogenicity to the VEGF Trap molecule either [28]. However, on February 13, 2012, the American Society of Retina Specialists, in a letter to its members, and Regeneron, in a letter to the FDA, described a number of reported cases of ocular inflammation/noninfectious endophthalmitis following intravitreal injection of aflibercept for the treatment of neovascular AMD. It is unclear at this time if such inflammation will continue to be observed in the future and if it will affect the usage of VEGF Trap-Eye among clinicians.

\section{DISCUSSION}

Anti-VEGF therapy has revolutionized the management of neovascular AMD, allowing nearly all patients to maintain their vision, while providing some patients with a gain of 15 or more Early Treatment Diabetic Retinopathy Study (ETDRS)letters. Remarkable therapies, such as RBZ or BVZ, have enabled many elderly patients with neovascular AMD to preserve their vision and consequently their independence; a tremendous societal benefit.

The approval of aflibercept offers another therapeutic option for patients with neovascular AMD. Aflibercept offers the potential of achieving the efficacy that patients and physicians have come to expect from current anti-VEGF agents, but with possibly less frequent injections and possibly no monitoring requirements. This may further decrease the number of annual office visits for AMD patients and their family members.

Although lesser frequency of treatments is expected with aflibercept (compared to BVZ or RBZ), the gain in VA has been similar among these three pharmacologic agents. Such findings may suggest that maximum visual gain has been achieved with aflibercept, BVZ, and RBZ as VEGF antagonists. Inhibiting other pathways involved in the pathogenesis of neovascular AMD and/or combination therapy may be required to achieve additional gain, supporting the rationale for additional research and clinical trials to search for other novel therapeutic approaches.

\section{CONCLUSION}

VEGF antagonists have brought better therapeutic outcomes, compared to laser therapy, to patients with neovascular AMD, DME, and RVO. Starting with pegaptanib followed by RBZ, BVZ, and most recently aflibercept, each of these agents has confirmed again the important role of VEGF in the pathogenesis of many retinal vascular diseases. Aflibercept appears to provide longer duration of efficacy compared to RBZ in neovascular AMD, while being investigated further in DME and RVO. The safety profile of anti-VEGF therapy, in published studies thus far, has not shown to be very different among different agents.

Studies are being done and research is being conducted to search for additional therapeutic approaches to enable patients with different retinal vascular diseases, including AMD, DME, and RVO, to achieve further visual gain while confronting no additional safety concerns.

\section{ACKNOWLEDGMENTS}

The John Hopkins University has received research funding from Regeneron, Genentech, Pfizer, Novartis, among others, to conduct 
studies in age-related macular degeneration (AMD). Q.D.N. is the guarantor for this article, and takes responsibility for the integrity of the work as a whole.

Conflicts of Interest. Q.D.N. serves on the Steering Committee for the VIEW Study of aflibercept (VEGF Trap-Eye) for neovascular AMD. No other authors have any conflicts of interests.

Open Access. This article is distributed under the terms of the Creative Commons Attribution Noncommercial License which permits any noncommercial use, distribution, and reproduction in any medium, provided the original author(s) and source are credited.

\section{REFERENCES}

1. Augood C, Fletcher A, Bentham G, et al. Methods for a population-based study of the prevalence of and risk factors for age-related maculopathy and macular degeneration in elderly European populations: the EUREYE study. Ophthalmic Epidemiol. 2004;11:117-29.

2. Bressler NM. Age-related macular degeneration is the leading cause of blindness. JAMA. 2004;291:1900-1.

3. Friedman DS, O'Colmain BJ, Munoz B, et al. Prevalence of age-related macular degeneration in the United States. Arch Ophthalmol. 2004;122:564-72.

4. Resnikoff S, Pascolini D, Etya'ale D, et al. Global data on visual impairment in the year 2002. Bull World Health Organ. 2004;82:844-51.

5. Congdon N, O'Colmain B, Klaver CC, et al. Causes and prevalence of visual impairment among adults in the United States. Arch Ophthalmol. 2004;122:477-85.

6. Barbazetto I, Burdan A, Bressler NM, et al. Photodynamic therapy of subfoveal choroidal neovascularization with verteporfin: fluorescein angiographic guidelines for evaluation and treatment - TAP and VIP report No. 2. Arch Ophthalmol. 2003;121:1253-68.

7. Engelbert M, Zweifel SA, Freund KB. Longterm follow-up for type 1 (subretinal pigment epithelium) neovascularization using a modified "treat and extend" dosing regimen of intravitreal antivascular endothelial growth factor therapy. Retina. 2010;30:1368-75.

8. Engelbert $M$, Zweifel SA, Freund KB. "Treat and extend" dosing of intravitreal antivascular endothelial growth factor therapy for type 3 neovascularization/retinal angiomatous proliferation. Retina. 2009;29:1424-31.

9. Freund KB, Zweifel SA, Engelbert M. Do we need a new classification for choroidal neovascularization in age-related macular degeneration? Retina. 2010;30:1333-49.

10. Argon laser photocoagulation for senile macular degeneration. Results of a randomized clinical trial. Arch Ophthalmol. 1982;100:912-8.

11. Argon laser photocoagulation for neovascular maculopathy. Three-year results from randomized clinical trials. Macular Photocoagulation Study Group. Arch Ophthalmol. 1986;104:694-701.

12. Argon laser photocoagulation for neovascular maculopathy. Five-year results from randomized clinical trials. Macular Photocoagulation Study Group. Arch Ophthalmol. 1991;109:1109-14.

13. Five-year follow-up of fellow eyes of patients with age-related macular degeneration and unilateral extrafoveal choroidal neovascularization. Macular Photocoagulation Study Group. Arch Ophthalmol. 1993;111:1189-99.

14. 1Visudyne provides for the treatment of agerelated macular degeneration in patients with predominantly classic subfoveal choroidal neovascularization. 2000; Available at: http:// www.fda.gov/Drugs/DevelopmentApprovalProcess/ HowDrugsareDevelopedandApproved/ DrugandBiologicApprovalReports/ucm081685. htm. Accessed Jun 12011.

15. Photodynamic therapy of subfoveal choroidal neovascularization in age-related macular degeneration with verteporfin: one-year results of 2 randomized clinical trials - TAP report. Treatment of age-related macular degeneration with photodynamic therapy (TAP) Study Group. Arch Ophthalmol. 1999;117:1329-45.

16. Blinder KJ, Bradley S, Bressler NM, et al. Effect of lesion size, visual acuity, and lesion composition on visual acuity change with and without verteporfin therapy for choroidal neovascularization secondary to age-related macular degeneration: TAP and VIP report no. 1. Am J Ophthalmol. 2003;136:407-18. 
17. FDA approves new drug treatment for age-related macular degeneration. Dec 20 2004; Available at: http://www.fda.gov/newsevents/newsroom/ pressannouncements/2004/ucm108385.htm. Accessed Sep 12011.

18. FDA approves new biologic treatment for wet agerelated macular degeneration. 2006; Available at: http://www.fda.gov/NewsEvents/Newsroom/ PressAnnouncements/2006/ucm108685.htm. Accessed Sep 12011.

19. Regeneron announces FDA approval of EYLEA ${ }^{\mathrm{TM}}$ (aflibercept) injection for the treatment of wet agerelated macular degeneration: CORRECTED. Nov. 18, 2011 Available at: http://newsroom.regeneron. com/releasedetail.cfm?ReleaseID=625771. Accessed Dec 12011.

20. Bressler NM, Bressler SB, Childs AL, et al. Surgery for hemorrhagic choroidal neovascular lesions of age-related macular degeneration: ophthalmic findings: SST report no. 13. Ophthalmology. 2004;111:1993-2006.

21. Hawkins BS, Bressler NM, Miskala PH, et al. Surgery for subfoveal choroidal neovascularization in age-related macular degeneration: ophthalmic findings: SST report no. 11. Ophthalmology. 2004;111:1967-1980.

22. Skaf AR, Mahmoud T. Surgical treatment of agerelated macular degeneration. Semin Ophthalmol. 2011;26:181-91.

23. Ibrahim AM, Channa R, Nguyen QD. Novel antiVEGF drugs in ARMD currently in trials. In: Das A, Friberg TR, eds. Therapy for Ocular Angiogenesis: Principles and Practice. Section II, Chapter 2. 1st edition. Philadelphia, PA: Lippincott Williams \& Wilkins; 2010.

24. Chappelow AV, Kaiser PK. Neovascular age-related macular degeneration: potential therapies. Drugs. 2008;68:1029-36.

25. Kuo CJ, Farnebo F, Yu EY, et al. Comparative evaluation of the antitumor activity of antiangiogenic proteins delivered by gene transfer. Proc Natl Acad Sci USA. 2001;98:4605-10.

26. Holash J, Davis S, Papadopoulos N, et al. VEGFTrap: a VEGF blocker with potent antitumor effects. Proc Natl Acad Sci USA. 2002;99:11393-8.

27. Chu QS. Aflibercept (AVE0005): an alternative strategy for inhibiting tumour angiogenesis by vascular endothelial growth factors. Expert Opin Biol Ther. 2009;9:263-71.
28. VEGF Trap-Eye (aflibercept ophthalmic solution) Briefing Document. June 17. Regeneron Pharmaceuticals; 2011. Available at : http:// www.fda.gov/downloads/AdvisoryCommittees/ CommitteesMeetingMaterials/Drugs/ DermatologicandOpthalmicDrugsAdvisory Comittee/UCM259143.pdf. Accessed May 152012.

29. Stewart MW, Rosenfeld PJ. Predicted biological activity of intravitreal VEGF Trap. Br J Ophthalmol. 2008;92:667-8.

30. Bakri SJ, Snyder MR, Reid JM, Pulido JS, Singh RJ. Pharmacokinetics of intravitreal bevacizumab (Avastin). Ophthalmology. 2007;114:855-9.

31. Bakri SJ, Snyder MR, Reid JM, Pulido JS, Ezzat MK, Singh RJ. Pharmacokinetics of intravitreal ranibizumab (Lucentis). Ophthalmology. 2007;114:2179-82.

32. Sinapis CI, Routsias JG, Sinapis AI, et al. Pharmacokinetics of intravitreal bevacizumab (Avastin(R)) in rabbits. Clin Ophthalmol. 2011;5:697-704.

33. Vinores SA. Pegaptanib in the treatment of wet, age-related macular degeneration. Int $\mathrm{J}$ Nanomedicine. 2006;1:263-8.

34. Gaudreault J, Fei D, Beyer JC, et al. Pharmacokinetics and retinal distribution of ranibizumab, a humanized antibody fragment directed against VEGF-A, following intravitreal administration in rabbits. Retina. 2007;27:1260-6.

35. Gaudreault J, Fei D, Rusit J, Suboc P, Shiu V. Preclinical pharmacokinetics of Ranibizumab (rhuFabV2) after a single intravitreal administration. Invest Ophthalmol Vis Sci. 2005;46:726-33.

36. Patel $M$ WL, Hutmacher $M$, et al. Population pharmacokinetics/pharmacodynamics (PK/PD) of pegaptanib sodium (Macugen) in patients with age-related macular degeneration (AMD). Presented at ARVO (Assoc for Research in Vision and Ophthalmology). April 30 - May 4, 2006; Fort Lauderdale, Florida, USA. Program 2623.

37. FDA approves Lucentis® (Ranibizumab Injection) for the treatment of macular edema following retinal vein occlusion. June 22, 2010. Available at: http://www.gene.com/gene/news/press-releases/ display.do?method=detail\&id=12827. Accessed Sep 12011.

38. Pazdur R. FDA approval for bevacizumab. National Cancer Institute; 2011. Available at: http:// 
www.cancer.gov/cancertopics/druginfo/fdabevacizumab. Accessed Dec 12011.

39. Dvorak HF, Brown LF, Detmar M, Dvorak AM. Vascular permeability factor/vascular endothelial growth factor, microvascular hyperpermeability, and angiogenesis. Am J Pathol. 1995;146:1029-39.

40. Holmes DI, Zachary I. The vascular endothelial growth factor (VEGF) family: angiogenic factors in health and disease. Genome Biol. 2005;6:209.

41. Olsson AK, Dimberg A, Kreuger J, Claesson-Welsh L. VEGF receptor signalling - in control of vascular function. Nat Rev Mol Cell Biol. 2006;7:359-71.

42. Carmeliet P, Moons L, Luttun A, et al. Synergism between vascular endothelial growth factor and placental growth factor contributes to angiogenesis and plasma extravasation in pathological conditions. Nat Med. 2001;7:575-83.

43. Rakic JM, Lambert V, Devy L, et al. Placental growth factor, a member of the VEGF family, contributes to the development of choroidal neovascularization. Invest Ophthalmol Vis Sci. 2003;44:3186-93.

44. Ziche M, Maglione D, Ribatti D, et al. Placenta growth factor-1 is chemotactic, mitogenic, and angiogenic. Lab Invest. 1997;76:517-31.

45. Bhisitkul RB. Vascular endothelial growth factor biology: clinical implications for ocular treatments. Br J Ophthalmol. 2006;90:1542-7.

46. Kvanta A, Algvere PV, Berglin L, Seregard S. Subfoveal fibrovascular membranes in age-related macular degeneration express vascular endothelial growth factor. Invest Ophthalmol Vis Sci. 1996;37:1929-34.

47. Kliffen M, Sharma HS, Mooy CM, Kerkvliet S, de Jong PT. Increased expression of angiogenic growth factors in age-related maculopathy. $\mathrm{Br} \mathrm{J}$ Ophthalmol. 1997;81:154-62.

48. Economides AN, Carpenter LR, Rudge JS, et al. Cytokine traps: multi-component, high-affinity blockers of cytokine action. Nat Med. 2003;9:47-52.

49. Investigator's brochure VEGF Trap Intravitreal Administration. April 5, 2005 Regeneron Pharmaceuticals, Inc. Tarrytown, NY, USA.

50. Lockhart AC, Rothenberg ML, Dupont J, et al. Phase I study of intravenous vascular endothelial growth factor trap, aflibercept, in patients with advanced solid tumors. J Clin Oncol. 2010;28:207-14.
51. Konner J, Dupont J. Use of soluble recombinant decoy receptor vascular endothelial growth factor trap (VEGF Trap) to inhibit vascular endothelial growth factor activity. Clin Colorectal Cancer. 2004;4:S81-85.

52. Dixon JA, Oliver SC, Olson JL, Mandava N. VEGF Trap-Eye for the treatment of neovascular agerelated macular degeneration. Expert Opin Investig Drugs. 2009;18:1573-80.

53. Stewart MW. What are the half-lives of ranibizumab and aflibercept (VEGF Trap-eye) in human eyes? Calculations with a mathematical model. Eye Reports. 2011;1:1.

54. Thai HT, Veyrat-Follet C, Vivier N, et al. A mechanism-based model for the population pharmacokinetics of free and bound aflibercept in healthy subjects. $\mathrm{Br} \mathrm{J}$ Clin Pharmacol. 2011;72:402-14.

55. Rudge JS, Holash J, Hylton D, et al. VEGF Trap complex formation measures production rates of VEGF, providing a biomarker for predicting efficacious angiogenic blockade. Proc Natl Acad Sci USA. 2007;104:18363-70.

56. Brown DM, Heier JS, Ciulla T, et al. Primary endpoint results of a phase II study of vascular endothelial growth factor Trap-Eye in wet agerelated macular degeneration. Ophthalmology. 2011;118:1089-97.

57. Regeneron and Bayer report positive results for VEGF Trap-Eye in second phase 3 study in central retinal vein occlusion. April 27, 2011. Available at: http://investor.regeneron.com/releasedetail. cfm?ReleaseID=572585. Accessed Sep 12011.

58. Do DV, Schmidt-Erfurth U, Gonzalez VH, et al. The DA VINCI Study: phase 2 primary results of VEGF Trap-Eye in patients with diabetic macular edema. Ophthalmology. 2011;118:1819-26.

59. Do DV, Nguyen QD, Shah SM, et al. An exploratory study of the safety, tolerability and bioactivity of a single intravitreal injection of vascular endothelial growth factor Trap-Eye in patients with diabetic macular oedema. Br J Ophthalmol. 2009;93:144-9.

60. Saishin Y, Takahashi K, Lima e Silva R, et al. VEGFTRAP(R1R2) suppresses choroidal neovascularization and VEGF-induced breakdown of the blood-retinal barrier. J Cell Physiol. 2003;195:241-8.

61. Nguyen QD, Shah SM, Hafiz G, et al. A phase I trial of an IV-administered vascular endothelial growth factor trap for treatment in patients with choroidal 
neovascularization due to age-related macular degeneration. Ophthalmology. 2006;113:1522.e1-14.

62. Boyer D. VEGF Trap for the Treatment of Neovascular AMD: VIEW 1 and VIEW II phase 3 studies showed the molecule to be noninferior to ranibizumab. Retina Today. April 2011. Available at: http://bmctoday.net/retinatoday/2011/04/ article.asp?f=vegf-trap-for-the-treatment-ofneovascular-amd. Accessed May 12012.

63. Vascular endothelial growth factor (VEGF) Trap-Eye: Investigation of efficacy and safety in central retinal vein occlusion (CRVO). July 10, 2009; Available at: http://clinicaltrials.gov/ ct2/show/NCT00943072?intr=\%22VEGF+TrapEye+2.0mg\%22\&rank=1. Accessed Sep 12011.

64. Vascular endothelial growth factor (VEGF) TrapEye: Investigation of efficacy and safety in wet age-related macular degeneration (AMD) (VIEW 1). July 31, 2007. Available at: http://clinicaltrials.gov/ ct2/show/NCT00509795?term=VIEW+1+amd\&ran $\mathrm{k}=1$. Accessed Sep 12011.

65. DME And VEGF Trap-Eye: INvestigation of Clinical Impact (DA VINCI). May 2, 2011. Available at: http://clinicaltrials.gov/ct2/show/NCT00789477?te rm=DME+And+VEGF+Trap-Eye\%3A+INvestigation +of+Clinical+Impact\&rank=1. Accessed Sep 12011.

66. VEGF Trap-Eye shows positive results in a phase 2 study in patients with diabetic macular edema - statistically significant improvement in vision achieved over 24 weeks. [press release] Feb 18, 2010. Available at: http://investor.regeneron. com/releasedetail.cfm?releaseid $=445521$.

Accessed Sep 12011.

67. Regeneron and Bayer announce start of phase 3 clinical program in diabetic macular edema. April 8, 2011. Available at: http://investor.regeneron. com/releasedetail.cfm?ReleaseID $=564466$. Accessed Sep 12011.

68. Highlights of prescribing information: EYLEA ${ }^{\mathrm{TM}}$ (aflibercept) injection for intravitreal injection initial U.S. Approval: 2011. Available at: http:// www.regeneron.com/Eylea/eylea-fpi.pdf. Accessed Feb 12012.

69. Gragoudas ES, Adamis AP, Cunningham ET, Jr., Feinsod M, Guyer DR. Pegaptanib for neovascular age-related macular degeneration. N Engl J Med. 2004;351:2805-16.

70. Chakravarthy U, Adamis AP, Cunningham ET, Jr., et al. Year 2 efficacy results of 2 randomized controlled clinical trials of pegaptanib for neovascular age-related macular degeneration. Ophthalmology. 2006;113:1508.e1-25.

71. Rosenfeld PJ, Brown DM, Heier JS, et al. Ranibizumab for neovascular age-related macular degeneration. N Engl J Med. 2006;355:1419-31.

72. Brown DM, Kaiser PK, Michels M, et al. Ranibizumab versus verteporfin for neovascular age-related macular degeneration. N Engl J Med. 2006;355:1432-44.

73. Brown DM, Michels M, Kaiser PK, Heier JS, Sy JP, Ianchulev T. Ranibizumab versus verteporfin photodynamic therapy for neovascular age-related macular degeneration: Two-year results of the ANCHOR study. Ophthalmology. 2009;116:57-65.e5.

74. Heier JS, Boyer DS, Ciulla TA, et al. Ranibizumab combined with verteporfin photodynamic therapy in neovascular age-related macular degeneration: year 1 results of the FOCUS Study. Arch Ophthalmol. 2006;124:1532-42.

75. Antoszyk AN, Tuomi L, Chung CY, Singh A. Ranibizumab combined with verteporfin photodynamic therapy in neovascular age-related macular degeneration (FOCUS): year 2 results. Am J Ophthalmol. 2008;145:862-74.

76. Regillo CD, Brown DM, Abraham $\mathrm{P}$, et al. Randomized, double-masked, sham-controlled trial of ranibizumab for neovascular age-related macular degeneration: PIER Study year 1 . Am J Ophthalmol. 2008;145:239-48.

77. Abraham P, Yue H, Wilson L. Randomized, doublemasked, sham-controlled trial of ranibizumab for neovascular age-related macular degeneration: PIER study year 2. Am J Ophthalmol. 2010;150:315-24.e1.

78. Fung AE, Lalwani GA, Rosenfeld PJ, et al. An optical coherence tomography-guided, variable dosing regimen with intravitreal ranibizumab (Lucentis) for neovascular age-related macular degeneration. Am J Ophthalmol. 2007;143:566-83.

79. Lalwani GA, Rosenfeld PJ, Fung AE, et al. A variable-dosing regimen with intravitreal ranibizumab for neovascular age-related macular degeneration: year 2 of the PrONTO Study. Am J Ophthalmol. 2009;148:43-58.e1.

80. Tufail A, Patel PJ, Egan C, et al. Bevacizumab for neovascular age related macular degeneration (ABC Trial): multicentre randomised double masked study. BMJ. 2010;340:c2459.

81. Martin DF, Maguire MG, Ying GS, Grunwald JE, Fine SL, Jaffe GJ. Ranibizumab and bevacizumab 
for neovascular age-related macular degeneration. N Engl J Med. 2011;364:1897-908.

82. Spaide R. Ranibizumab according to need: a treatment for age-related macular degeneration. Am J Ophthalmol. 2007;143:679-80.

83. Gupta OP, Shienbaum G, Patel AH, Fecarotta C, Kaiser RS, Regillo CD. A treat and extend regimen using ranibizumab for neovascular age-related macular degeneration clinical and economic impact. Ophthalmology. 2010;117:2134-40.

84. Shienbaum G, Gupta OP, Fecarotta C, Patel AH, Kaiser RS, Regillo CD. Bevacizumab for neovascular age-related macular degeneration using a treat-andextend regimen: clinical and economic impact. Am J Ophthalmol. 2012;153:468-73.e1

85. Oubraham H, Cohen SY, Samimi S, et al. Inject and extend dosing versus dosing as needed: a comparative retrospective study of ranibizumab in exudative age-related macular degeneration. Retina. 2011;31:26-30.

86. Cao J, Zhao L, Li Y, et al. A subretinal matrigel rat choroidal neovascularization (CNV) model and inhibition of $\mathrm{CNV}$ and associated inflammation and fibrosis by VEGF trap. Invest Ophthalmol Vis Sci. 2010;51:6009-17.

87. Nguyen QD, Shah SM, Browning DJ, et al. A phase I study of intravitreal vascular endothelial growth factor trap-eye in patients with neovascular agerelated macular degeneration. Ophthalmology. 2009;116:2141-8.e1.

88. Nguyen QD. A randomized comparison of the safety, tolerability, and bioactivity study of two dose levels of intra-vitreal VEGF trap in patients with neovascular age-related macular degeneration. Presented at: Retina Society Annual Scientific Meeting; Sep 27-30 2007; Boston, MA, USA.

89. Heier JS, Boyer D, Nguyen QD, et al. The 1-year results of CLEAR-IT 2, a phase 2 study of vascular endothelial growth factor trap-eye dosed as-needed after 12-week fixed dosing. Ophthalmology. 2011;118:1098-106.

90. Enrollment completed in Regeneron and Bayer HealthCare phase 3 studies of VEGF Trap-Eye in neovascular age-related macular degeneration (wet AMD). September 14, 2009. Available at: http://newsroom.regeneron.com/releasedetail. cfm?ReleaseID=408872. Accessed Oct 12011.

91. Bayer and Regeneron report positive top-line results of two phase 3 studies with VEGF Trap-
Eye in wet age-related macular degeneration [press release]. Nov. 22, 2010. Available at: http://newsroom.regeneron.com/releasedetail. cfm?releaseid=532099. Accessed Oct 12011.

92. Vascular endothelial growth factor (VEGF) TrapEye: Investigation of efficacy and safety in wet age-related macular degeneration (AMD) (VIEW 2). March 12, 2008. Available at: http://clinicaltrials. gov/ct2/show/NCT00637377?term=VIEW+1+amd \&rank=2. Accessed Oct 12011.

93. Two year results of phase 3 studies with EYLEA ${ }^{\mathrm{TM}}$ (aflibercept) injection in wet AMD show sustained improvement in visual acuity. December 5, 2011. Available at: http://newsroom.regeneron.com/ releasedetail.cfm?ReleaseID $=629800$. Accessed Feb 1 2012.

94. Regeneron and Bayer report positive results for VEGF Trap-Eye in phase 3 study in central retinal vein occlusion (CRVO) and in phase 2 study in diabetic macular edema (DME). December 20, 2010. Available at: http://www.press.bayer.com/ baynews/baynews.nsf/id/Bayer-Regeneron-ReportPositive-Results-VEGF-Trap-Eye-Central-RetinalVein-Occlusion-Diabetic. Accessed Oct 12011.

95. Boyer D. Galileo: aflibercept improved visual acuity in CRVO. Retina Today. JUNE 2011. Available at: http://bmctoday.net/retinatoday/2011/06/article. asp?f=galileo-aflibercept-improved-visual-acuity-incrvo. Accessed May 152012.

96. Brown DM, Campochiaro PA, Singh RP, et al. Ranibizumab for macular edema following central retinal vein occlusion: six-month primary end point results of a phase III study. Ophthalmology. 2010;117:1124-33.e1.

97. Campochiaro PA, Brown DM, Awh CC, et al. Sustained benefits from ranibizumab for macular edema following central retinal vein occlusion: twelve-month outcomes of a phase III study. Ophthalmology. 2011;118:2041-9.

98. Heier JS, Campochiaro PA, Yau L, et al. Ranibizumab for macular edema due to retinal vein occlusions long-term follow-up in the HORIZON Trial. Ophthalmology. 2012;119:802-9.

99. Jager RD, Aiello LP, Patel SC, Cunningham ET, Jr. Risks of intravitreous injection: a comprehensive review. Retina. 2004;24:676-98.

100. Csaky K, Do DV. Safety implications of vascular endothelial growth factor blockade for subjects receiving intravitreal anti-vascular endothelial growth factor therapies. Am J Ophthalmol. 2009;148:647-56. 
101. van der Reis MI, La Heij EC, De Jong-Hesse Y, Ringens PJ, Hendrikse F, Schouten JS. A systematic review of the adverse events of intravitreal anti-vascular endothelial growth factor injections. Retina. 2011;31:1449-69.

102. McCannel CA. Meta-analysis of endophthalmitis after intravitreal injection of anti-vascular endothelial growth factor agents: causative organisms and possible prevention strategies. Retina. 2011;31:654-61.

103. Los M, Roodhart JM, Voest EE. Target practice: lessons from phase III trials with bevacizumab and vatalanib in the treatment of advanced colorectal cancer. Oncologist. 2007;12:443-50.

104. Bouchon B, Chambon C, Mounetou E, et al. Alkylation of beta-tubulin on Glu 198 by a microtubule disrupter. Mol Pharmacol. 2005;68:1415-22.

105. Schmidt-Erfurth U. Clinical safety of ranibizumab in age-related macular degeneration. Expert Opin Drug Saf. 2010;9:149-65.

106. Boyer DS, Heier JS, Brown DM, Francom SF, Ianchulev $\mathrm{T}$, Rubio RG. A phase IIIb study to evaluate the safety of ranibizumab in subjects with neovascular age-related macular degeneration. Ophthalmology. 2009;116:1731-9.

107. Gaudreault J, Shiu V, Bricarello A, Christian BJ, Zuch CL, Mounho B. Concomitant administration of bevacizumab, irinotecan, 5-fluorouracil, and leucovorin: nonclinical safety and pharmacokinetics. Int J Toxicol. 2005;24:357-63. 